\title{
Real Convergence Across the Euro Area
}

\section{What Role Do Macroeconomic Imbalances Play?}

This paper studies the relationship between real convergence in the euro area and macroeconomic imbalances. It compares the main features of convergence within the euro area with other EU and non-EU country groups, looking at both 'sigma' and 'beta' convergence in output and total factor productivity. Expected convergence paths for euro area countries are estimated using growth regressions run on a large panel of advanced and emerging market economies and compared to actual growth. The findings support the view that EU and euro area countries display similar convergence patterns to those of other country groups, while the group of countries that adopted the euro first exhibit relatively weak convergence since before the financial crisis. Such differences could be partly linked to relatively low dispersion in per capita incomes across this country group, although lack of convergence is also largely due to persisting differences in total factor productivity performance. The findings also suggest that macroeconomic imbalances accumulated in the pre-crisis period such as high private and government debt and strong growth in the non-tradable sector have been associated with lower convergence, particularly for euro area countries.

In the run-up to the Economic and Monetary Union (EMU), the Maastricht criteria emphasised nominal convergence as a requirement for achieving a stable common currency, with the entry criteria requiring convergence in nominal variables including inflation, interest and exchange rates, public deficits and debts. At the same time, the academic debate was largely focused on the desirable characteris-

(C) The Author(s) 2020. Open Access: This article is distributed under the terms of the Creative Commons Attribution 4.0 International License (https://creativecommons.org/licenses/by/4.0/).

Open Access funding provided by ZBW - Leibniz Information Centre for Economics.

* The authors thank the participants of the European Central Bank Surveillance Workshop in Frankfurt on 19 October 2017, and in particular David Sondermann, for useful comments and suggestions. We also thank Marco Buti and José Leandro for useful comments on an earlier version of the paper. All remaining mistakes are the authors' solely. The views expressed in this paper are those of the authors and should not be attributed to the European Commission.

Leonor Coutinho, European Commission, Brussels, Belgium.

Alessandro Turrini, European Commission, Brussels, Belgium. tics of countries sharing a common currency. In line with the optimal currency area (OCA) theory (Mundell, 1961), countries ought to be sufficiently similar and integrated to reduce the likelihood of asymmetric shocks and have flexible product and labour markets to lower the costs of adjusting in the absence of nominal exchange rates. In this respect, the academic debate in the period preceding the EMU was focused on real rather than on nominal convergence, emphasising the structural transformations along the convergence process that would reduce differences in economic institutions, the occurrence of asymmetric shocks and adjustment costs in a monetary union.

During the first decade of the EMU, nominal convergence appeared to go hand in hand with real convergence. Nominal interest rates converged on the back of financial integration and a reduction in perceived risks. In anticipation of a stable currency and no redenomination risks, both the mean and the variance of ten-year government bond rates across 12 euro area (EA) countries dropped significantly between 1994 and 1997 (see Figure 1). This process lasted for about a decade, but was interrupted by the European sovereign debt crisis of 2010-2012, during which this variance spiked to levels last seen only prior to the 1990s. Real convergence in per capita incomes was observed across the whole euro area but not among the EA11 (founding members including Greece but excluding 
Figure 1

\section{Nominal convergence in the euro area}

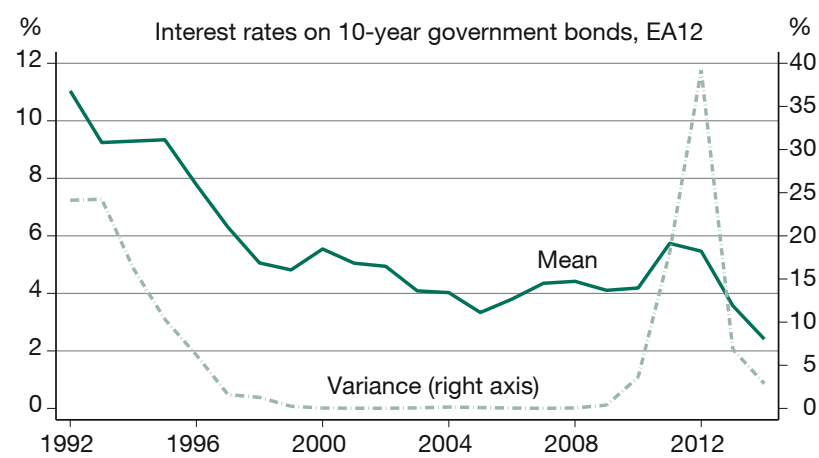

Source: AMECO database, European Commission

Luxembourg, see Figure 2), and divergent patterns became predominant in the years following the crisis.

Convergence patterns in the euro area have been closely connected to dynamics in capital flows and current account balances. In the run-up to the EMU, capital flew from countries in the euro area 'core' to the 'periphery'. Current account divergences were generally seen as supportive of the convergence process as capital moved from relatively high-income countries to relatively lowincome ones (Blanchard and Giavazzi, 2002). The global financial crisis, however, implied a reappraisal of risk and a sudden withdrawal of capital from the periphery. 'Sudden stops' in current accounts led to a major contraction

1 See also ECB (2015).

Figure 3

External balances in the euro area

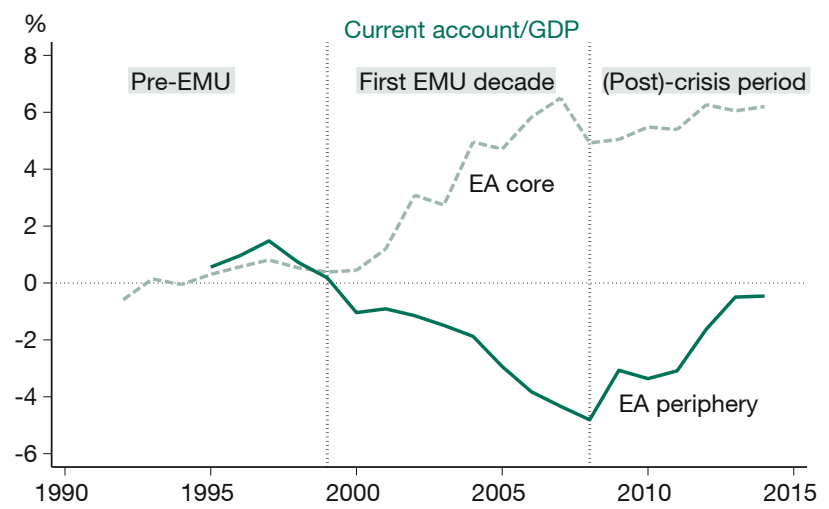

Note: Core includes BE DE LU NL AT FI. Periphery includes EE IE EL ES FR IT CY LV LT MT PT SI SK. Core and periphery euro area countries grouped according to their external position over the 1999-2009 period (GDP weights).

Source: Eurostat.
Figure 2

Real convergence in the euro area

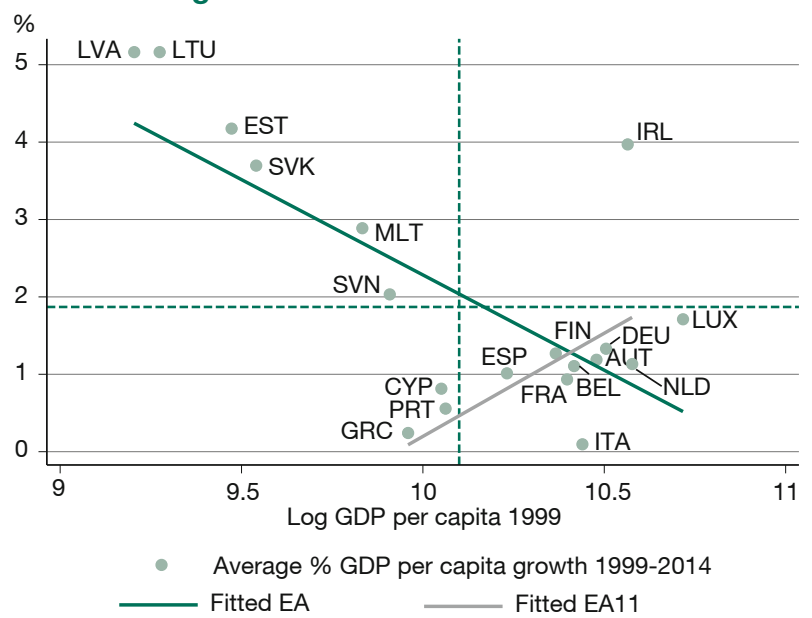

Source: Penn World Tables 9.1.

in domestic demand and a reversal in the convergence process (Diaz del Hoyo, 2017).

The dispersion in external positions was mirrored in diverging unemployment trends (see Figures 3 and 4). Between 1999 and 2007, the periphery was in a relatively strong cyclical position resulting in falling unemployment rates. Over the same period, cyclical positions were weaker in the core and unemployment increased between 2002 and 2005. This pattern reversed in the post-crisis period, when current account reversals were followed by surging unemployment in the periphery.

Figure 4

Unemployment in the euro area

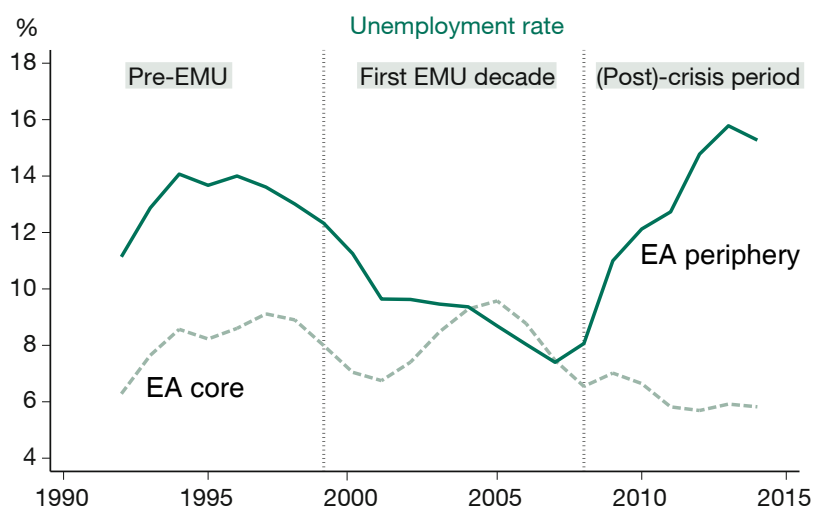

Note: Core and periphery defined as before.

Source: Eurostat. 
These developments had implications not only for the cycle but also for the growth potential. Prior to the crisis, the flow of investment to the periphery was channelled primarily to the non-tradable sector. This meant that persistent real interest rate differentials were reflected not only in the differences in cyclical positions, according to the Walters critique of the EMU, but also in divergent economic structures, notably the composition of output between tradables and non-tradables (Buti and Turrini, 2015). ${ }^{2}$ The growth of the non-tradable sector in the euro area periphery - in some cases the counterpart of largescale housing market bubbles - was generally accompanied by cost competitiveness losses and worsened the prospects for a more durable growth engine based on exports.

The aim of this paper is to test the hypothesis that precrisis macroeconomic imbalances had implications for real convergence within the euro area. Previous work has analysed the link between business cycle synchronisation and variables related to macroeconomic imbalances. ${ }^{3}$ The present instead focuses on the role of imbalances in explaining the pace of convergence.

In doing that, this paper goes a step further than existing companion papers in several respects. ${ }^{4}$ First, it assesses convergence patterns across the euro area against the experience of other non-EU and non-euro area benchmark country groups. To this purpose, a large panel including advanced and emerging economies is considered. Second, it explores convergence along different dimensions, not only in terms of per capita GDP but also in terms of total factor productivity (TFP). Both 'sigma' and 'beta' convergence are analysed. Third, it relates deviations from expected convergence paths to a number of variables associated with the presence of macroeconomic imbalances, including government and private debt, current account balances, net international investment positions (NIIP), credit flows and growth in the non-tradable sector.

\section{Real convergence in the euro area}

The dataset used in this analysis is a large panel of advanced and emerging economies, obtained mostly from the Summers-Heston Penn World Tables (PWT) version

2 Buti and Turrini (2010) argue that the economic structure shapes the way the economy responds to shocks. For instance, the excessive weight of the construction sector left several economies particularly vulnerable to the credit crunch experienced in the global financial crisis.

3 See Inklaar et al. (2008) and Lukmanova and Tondl (2017).

4 See Sondermann (2014), Estrada and López-Salido (2013), ECB (2015) and Diaz del Hoyo et al. (2017).
9.1. ${ }^{5}$ These contain comparable information on variables expressed in purchasing power parity for many countries and years.

Before turning to evidence on real convergence across the euro area, the notions of beta convergence and sigma convergence are recalled.

Unconditional beta convergence is observed when the growth rate of real per capita GDP is negatively related to the starting level of real per capita GDP.

Conditional beta convergence is observed when the growth rate of real per capita GDP is negatively related to the initial level of real GDP per capita, taking into account the impact of other variables that may affect growth. Formally,

$$
\Delta \log Y_{i t}=\alpha+\beta \log Y_{i t-1}+\zeta Z_{i t}+u_{i t}
$$

where, the average growth rate of country $i$ over a time period $t$ is approximated by the log difference of GDP per capita, $\Delta \log Y_{i t}$, and is put in relation with the level of GDP per capita at the start of the period $Y_{i t-1}$, a set of $Z_{i t}$ conditioning variables, and a random disturbance $u_{i t}$.

Beta convergence implies that poorer economies eventually catch up with richer countries by growing faster, hence parameter $\beta$ in equation (1) is expected to be negative. Moreover, conditional beta convergence implies that countries converge to steady-state growth rates that may differ depending on country characteristics.

The concept of sigma convergence relates to the crosssectional dispersion of income. There is sigma convergence if income dispersion across a specific group of countries declines over time. Abstracting from the set of conditioning variables $Z$, equation (1) can be rewritten as follows (see Barro Sala-i-Martin, 2004).

$$
\Delta \log Y_{i t}=\alpha-\left(1-\mathrm{e}^{-\lambda}\right) \log Y_{i t-1}+u_{i t}
$$

If $\lambda>0$, equation (2) implies that poor countries grow faster than rich ones (i.e. there is beta convergence). Defining the variance of $\log Y_{i t}$ as $\sigma_{t}^{2}$, equation (2) also implies

$$
\sigma_{t}^{2}=\mathrm{e}^{-2 \lambda} \sigma_{t-1}^{2}+\sigma_{t}^{2}
$$

where $\sigma_{t}^{2}$ is the variance of $u_{i t}$. Equation (3) implies that beta convergence is a necessary but not sufficient condition for sigma convergence (as $\lambda>0$ implies $\mathrm{e}^{-2 \lambda}<1$ ).

5 See Inklaar and Woltjer (2019). 
Figure 5

Sigma convergence: Standard deviation of log GDP per capita, 1995-2015

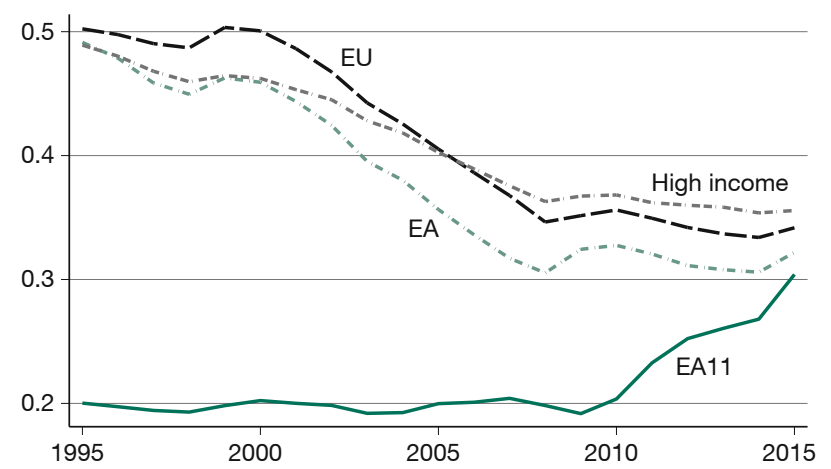

Sources: Penn World Tables 9.1.

Moreover, the fall in dispersion is stronger the higher the existing degree of dispersion $\sigma_{t-1}^{2}$.

\section{Sigma convergence}

To assess sigma convergence, Figures 5 and 6 show the standard deviation of log GDP per capita for the euro area, the EU, the EA11 and a broader group of high-income countries. Figure 5 displays data from 1995 to avoid missing data for former transition countries, while Figure 6 has a longer horizon by excluding transition countries from the country groups. The dynamics of income dispersion indicate that sigma convergence has been faster in the EU and the euro area than among other high-income countries. This confirms previous studies that regard the EU as a 'convergence club'. ${ }^{6}$ However, the group of EA11 countries displays convergence mostly up to the mid1970s (when the longer horizon is considered) and divergence after the global financial crisis, particularly when countries that underwent macroeconomic adjustment programmes in the aftermath of the global financial crisis are included.

In the neoclassical growth model (Solow, 1956; Swan, 1956), output convergence is driven by convergence in the capital stock. Incentives to invest are higher in countries with a relatively low capital stock and higher marginal productivity of capital. Figure 7 looks at convergence patterns in the capital stock per capita to check whether the neoclassical model prediction matches the data. The graph compares the EA11 group and the larger group of advanced non-transition economies since 1960 and the euro area countries since 1995 (due to missing data). It

6 See Böwer and Turrini (2010).
Figure 6

Sigma convergence: Standard deviation of log GDP per capita, 1960-2020

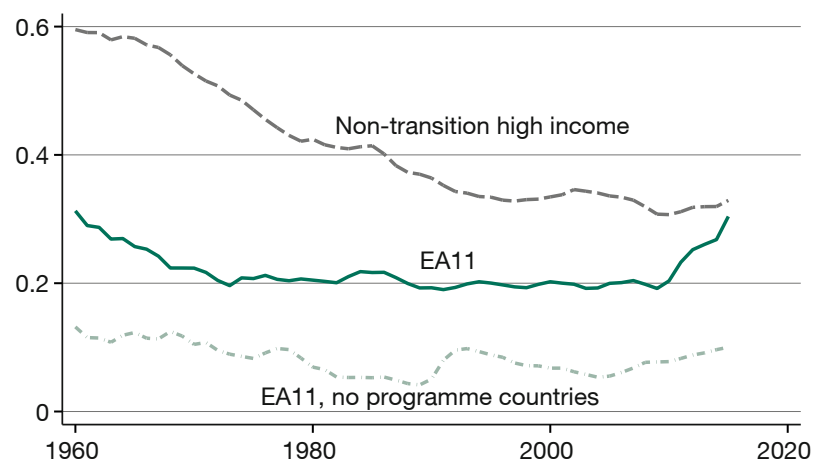

Sources: Penn World Tables 9.1.

appears that convergence is much more visible when looking at capital per capita rather than GDP per capita, including for the EA11 group. This confirms the standard mechanism of convergence from neoclassical growth theory.

Dynamics in GDP per capita may differ from those in capital per capita because of the impact of TFP. ${ }^{7}$ In modern growth theory, where TFP growth is the result of a process of innovation and gradual adoption of new vintage technologies, income convergence can also be driven by TFP convergence (Aghion and Howitt, 2006). Countries further away from the frontier have more room to grow by adopting better technologies that already exist. Figure 8 shows the standard deviation of TFP in the EA11. Some limited convergence seems to have played a role up until the 1990s. However, TFP dispersion fluctuated afterwards. There is more evidence of steady convergence for the broader set of advanced economies as well as for the euro area, despite the short time series available for the latter.

A comparison of sigma convergence for GDP per capita with that of GDP per employee is provided in Figure 9 for the EA11 group. The graph shows quite clearly that while the dispersion in the two variables co-moved quite closely over the whole period starting from the 1960s, an upward spike occured in GDP per capita after the crisis, whereas evidence of divergence is much more limited for the GDP per employee. This finding permits a better interpretation of the divergence process in the post-crisis period as a

7 Using a standard Cobb-Douglas production function, $y=A k^{\alpha}$, where $y$ and $k$ stand, respectively, for output and capital per worker and $A$ is TFP. 
Figure 7

Sigma convergence: Standard deviation of log capital per capita

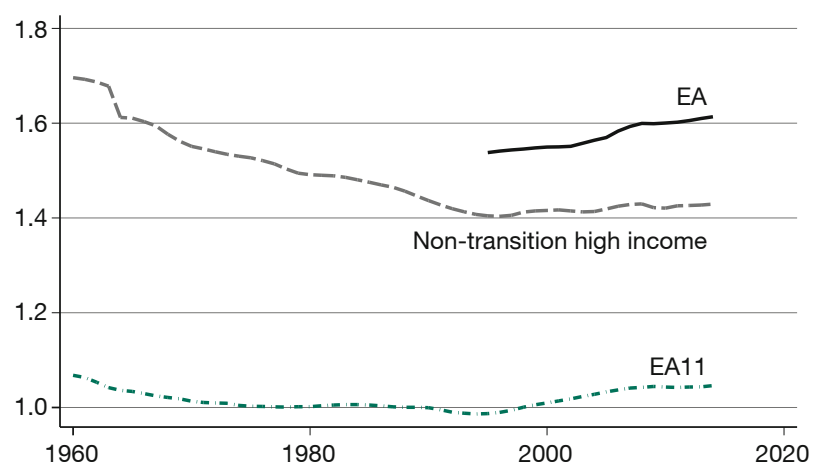

Sources: Penn World Tables 9.1.

Figure 8

Sigma convergence: Standard deviation of log TFP

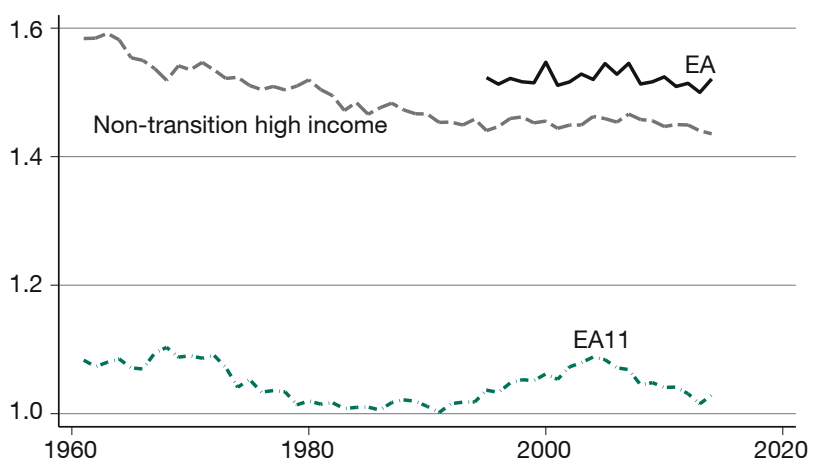

Sources: Penn World Tables 9.1.

Figure 9

Sigma convergence: GDP per capita vs GDP per employee - standard deviations, EA11

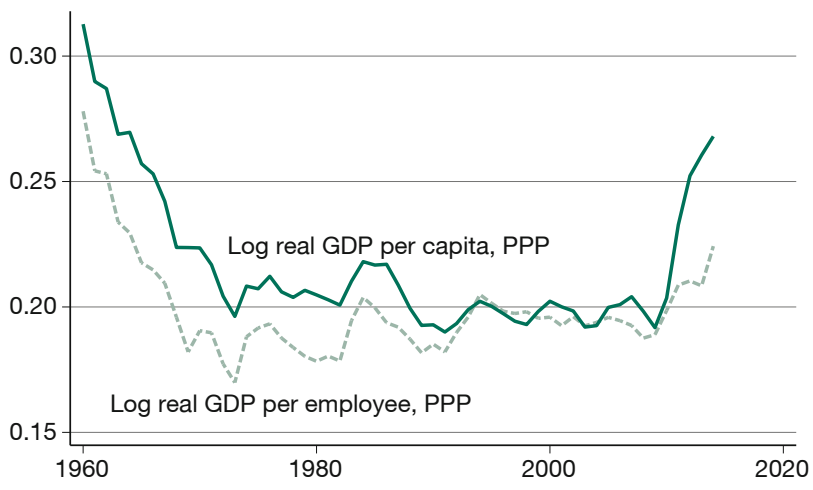

Sources: Penn World Tables 9.1. phenomenon that was not caused by strong divergence in capital per employee or TFP, but rather by a very large divergence in employment rates.

Overall, there is evidence of sigma convergence in the euro area occurring at rates similar to those observed across other country groups. For the EA11, sigma convergence appears to have occurred slowly up until the mid-1970s. The relatively slow rate of convergence in GDP per capita is partly due to the EA11 group being highly homogeneous in terms of income conditions. An additional factor that underpins the stall in income convergence is the lack of TFP convergence in recent decades. The divergence in income per capita in the postcrisis period is mainly linked to divergent employment rates. This phenomenon is likely transitory and concentrated in the few countries most affected by post-crisis recessions, induced by the unwinding of macroeconomic imbalances and debt crises.

The absence of sigma convergence does not imply absence of beta convergence. In other words, it does not exclude that in general countries with relatively low income per capita have witnessed faster growth, as the occurrence of certain types of shocks can produce dispersion.

\section{Beta convergence}

Beta convergence takes place when countries with a lower income per capita grow faster over a medium- to long-term period. Figure 2 shows prima facie evidence of beta convergence in the euro area. A more rigorous analysis also needs to take into account that growth rates across countries not only vary because of different initial income conditions, but also because of other factors that explain long-term growth performance. In this respect, growth regressions are estimated to take these variables into account as well. Evidence on convergence obtained from growth regressions are interpreted as a test for 'conditional' convergence. In addition to initial income per capita, growth rates are put in relation to other possible explanatory variables by means of a panel regression that exploits both cross-sectional and time-series variation. More specifically, the regression estimated is as follows:

$$
\Delta_{5} \log Y_{i t}=\alpha+\beta \log Y_{i t-5}+\zeta Z_{i t}+\gamma_{i}+\delta_{t}+\varepsilon_{i t},
$$

where the dependent variable $Y_{i t}$ is either output per capita (in PPP) or TFP and $Z_{i t}$ is a vector of control variables. The subscript $i$ refers to countries, and $t$ is the time period over which growth rates are computed. Following standard practice in the estimation of growth regressions 
Table 1

Conditional beta convergence: Output per capita

\begin{tabular}{|c|c|c|c|c|c|c|c|c|c|c|c|}
\hline $\begin{array}{l}\text { Dep var: GDP p.h. growth, } \\
5 \text {-year averages }\end{array}$ & $\begin{array}{c}\text { (1) } \\
\text { All } \\
\text { sample }\end{array}$ & $\begin{array}{c}\text { (2) } \\
\text { All } \\
\text { sample, IV }\end{array}$ & $\begin{array}{l}\text { (3) } \\
\text { EU }\end{array}$ & $\begin{array}{l}(4) \\
\mathrm{EA}\end{array}$ & $\begin{array}{c}(5) \\
\text { EA11 }\end{array}$ & $\begin{array}{c}(6) \\
E U>1999\end{array}$ & $\begin{array}{c}(7) \\
E A>1999\end{array}$ & $\begin{array}{c}(8) \\
\text { EA11>1999 }\end{array}$ & $\begin{array}{c}(9) \\
E U>2007\end{array}$ & $\begin{array}{c}(10) \\
E A>2007\end{array}$ & $\begin{array}{c}(11) \\
\text { EA11>2007 }\end{array}$ \\
\hline Ln GDP p.h. PPP, 5 lags & $\begin{array}{l}-2.266^{\star \star} \\
{[-6.80]}\end{array}$ & $\begin{array}{l}-2.566^{\star \star} \\
{[-7.04]}\end{array}$ & $\begin{array}{l}-3.072^{\star \star} \\
{[-6.91]}\end{array}$ & $\begin{array}{l}-2.802^{\star \star} \\
{[-6.43]}\end{array}$ & $\begin{array}{l}-0.749 \\
{[-0.86]}\end{array}$ & $\begin{array}{l}-3.905^{\star \star} \\
{[-7.97]}\end{array}$ & $\begin{array}{l}-4.149^{\star \star} \\
{[-7.11]}\end{array}$ & $\begin{array}{l}-2.291+ \\
{[-1.86]}\end{array}$ & $\begin{array}{r}-0.547 \\
{[-0.56]}\end{array}$ & $\begin{array}{c}-0.423 \\
{[-0.53]}\end{array}$ & $\begin{array}{r}7.148 \\
{[1.40]}\end{array}$ \\
\hline Human capital, 5 lags & $\begin{array}{l}0.436 \\
{[1.16]}\end{array}$ & $\begin{array}{l}0.566 \\
{[1.61]}\end{array}$ & $\begin{array}{l}0.366 \\
{[1.11]}\end{array}$ & $\begin{array}{c}0.479 \\
{[1.47]}\end{array}$ & $\begin{array}{l}-0.317 \\
{[-0.47]}\end{array}$ & $\begin{array}{l}1.355^{\star \star} \\
{[2.99]}\end{array}$ & $\begin{array}{l}1.541^{\star \star} \\
{[3.34]}\end{array}$ & $\begin{array}{l}1.311+ \\
{[2.11]}\end{array}$ & $\begin{array}{l}2.293^{\star *} \\
{[3.84]}\end{array}$ & $\begin{array}{l}2.655^{\star \star} \\
{[3.94]}\end{array}$ & $\begin{array}{r}-1.434 \\
{[-0.47]}\end{array}$ \\
\hline I/GDP, avg & $\begin{array}{l}10.422^{\star *} \\
{[6.76]}\end{array}$ & $\begin{array}{l}15.589^{* \star} \\
{[7.48]}\end{array}$ & $\begin{array}{l}8.211^{* *} \\
{[3.66]}\end{array}$ & $\begin{array}{l}5.003+ \\
{[1.90]}\end{array}$ & $\begin{array}{l}2.846 \\
{[0.86]}\end{array}$ & $\begin{array}{l}2.559 \\
{[0.46]}\end{array}$ & $\begin{array}{r}3.747 \\
{[0.54]}\end{array}$ & $\begin{array}{l}9.090 \\
{[0.69]}\end{array}$ & $\begin{array}{l}5.976 \\
{[0.55]}\end{array}$ & $\begin{array}{l}14.611 \\
{[1.46]}\end{array}$ & $\begin{array}{c}5.449 \\
{[0.27]}\end{array}$ \\
\hline Pop growth, avg & $\begin{array}{l}-0.449^{*} \\
{[-2.27]}\end{array}$ & $\begin{array}{l}-0.404^{*} \\
{[-2.17]}\end{array}$ & $\begin{array}{l}-0.437+ \\
{[-1.98]}\end{array}$ & $\begin{array}{l}-0.583^{\star} \\
{[-2.72]}\end{array}$ & $\begin{array}{l}-0.051 \\
{[-0.17]}\end{array}$ & $\begin{array}{l}-0.387 \\
{[-1.48]}\end{array}$ & $\begin{array}{l}-0.415 \\
{[-1.44]}\end{array}$ & $\begin{array}{r}0.173 \\
{[0.31]}\end{array}$ & $\begin{array}{l}-1.934^{\star *} \\
{[-2.92]}\end{array}$ & $\begin{array}{l}-2.516^{\star \star} \\
{[-6.34]}\end{array}$ & $\begin{array}{r}-0.750 \\
{[-0.20]}\end{array}$ \\
\hline Economic freedom, avg & $\begin{array}{l}0.514^{\star \star} \\
{[3.71]}\end{array}$ & $\begin{array}{l}0.470^{\star *} \\
{[3.45]}\end{array}$ & $\begin{array}{l}0.945^{\star *} \\
{[3.53]}\end{array}$ & $\begin{array}{c}0.498 \\
{[1.25]}\end{array}$ & $\begin{array}{l}0.344 \\
{[0.64]}\end{array}$ & $\begin{array}{l}1.303^{*} \\
{[2.62]}\end{array}$ & $\begin{array}{l}2.398^{\star \star} \\
{[3.52]}\end{array}$ & $\begin{array}{l}1.740+ \\
{[1.97]}\end{array}$ & $\begin{array}{l}3.356^{* *} \\
{[2.87]}\end{array}$ & $\begin{array}{l}3.177^{*} \\
{[2.29]}\end{array}$ & $\begin{array}{l}3.089 \\
{[1.18]}\end{array}$ \\
\hline Openness, avg & $\begin{array}{l}0.794^{*} \\
{[2.29]}\end{array}$ & $\begin{array}{l}0.565+ \\
{[1.81]}\end{array}$ & $\begin{array}{l}0.870+ \\
{[1.78]}\end{array}$ & $\begin{array}{l}1.350^{\star *} \\
{[2.98]}\end{array}$ & $\begin{array}{l}2.386 \\
{[1.64]}\end{array}$ & $\begin{array}{l}1.445^{\star *} \\
{[3.07]}\end{array}$ & $\begin{array}{l}1.316^{*} \\
{[2.59]}\end{array}$ & $\begin{array}{l}1.670 \\
{[1.12]}\end{array}$ & $\begin{array}{l}2.161^{* \star} \\
{[3.06]}\end{array}$ & $\begin{array}{l}2.216^{*} \\
{[2.41]}\end{array}$ & $\begin{array}{c}-1.376 \\
{[-0.54]}\end{array}$ \\
\hline Observations & 516 & 516 & 203 & 143 & 99 & 84 & 57 & 33 & 28 & 19 & 11 \\
\hline Countries & 66 & 66 & 28 & 19 & 11 & 28 & 19 & 11 & 28 & 19 & 11 \\
\hline R-squared & 0.41 & 0.40 & 0.57 & 0.64 & 0.62 & 0.70 & 0.74 & 0.54 & 0.71 & 0.83 & 0.80 \\
\hline
\end{tabular}

Note: Constant, time effects and regional effects included. Robust (clustered) t-statistics in brackets. ${ }^{\star *} \mathrm{p}<0.01,{ }^{*} \mathrm{p}<0.05,+\mathrm{p}<0.1$. I/GDP instrumented with investment deflator (5 lags). IV tests: Kleibergen-Paap rk Wald F statistic: 66.2; Exogeneity test (Hausman type) p-value: 0.3434.

Source: Authors' estimation.

with panel data, annual observations are converted into averages over five-year, non-overlapping sub-periods, in order to avoid short-term disturbances (see Barro Sala-iMartin, 2004).

The control variables capture factors that affect steadystate growth in the neoclassical growth model. Population growth accounts for the dilution of capital stock per capita and is associated with an expected negative coefficient. The share of investment in GDP serves as a proxy for the savings rate, which should be associated with faster capital accumulation (positive coefficient expected). A measure of human capital accumulation (the PWT 9.1 index of human capital based on years of schooling and return to education) is also included to account for investment in skills yielding improvements in labour input (a positive coefficient is expected). ${ }^{8}$ Two additional variables aim to control for factors that may affect TFP growth: openness to trade (imports plus exports as a share of GDP) accounts for the fact that open economies can import technology and know-how (Edwards 1996; Frenkel and Romer, 1999); quality of institutions, as measured by the Fraser index of economic freedom, takes into account the fact that good institutions are associated with stronger incentives to innovate and take risks (Glaeser et al., 2004). The terms $\gamma$ and $\delta$ are region and time effects,

8 See Mankiw et al. (1992). respectively. The inclusion of fixed effects capturing main world regions permits the control of unobserved factors specific to geographical areas without the loss of crosssection variation implied by a full set of country fixed effects (Temple, 1999).

The estimation results are shown in Table 1. Results are displayed for the full sample of 66 advanced and emerging economies and for country sub-samples and sub-periods. ${ }^{9}$ The control variables generally have the expected signs, even though some coefficients are not significant for all regions and periods. A well-known difficulty when estimating growth regressions is the possible endogeneity of investment, as this variable not only affects growth, but is also driven by expected growth rates. The issue does not seem to be relevant in these estimates, however, as the coefficient of the investment variable is qualitatively

9 Albania, Argentina, Australia, Austria, Belgium, Bulgaria, Brazil, Canada, Switzerland, Chile, China, Colombia, Costa Rica, Cyprus, Czechia, Germany, Denmark, Egypt, Spain, Estonia, Finland, France, the United Kingdom, Greece, Guatemala, Hong Kong, Croatia, Hungary, Indonesia, India, Ireland, Iceland, Israel, Italy, Japan, Korea, Sri Lanka, Lithuania, Luxembourg, Latvia, Morocco, Mexico, Malta, Malaysia, the Netherlands, Norway, New Zealand, Pakistan, Peru, the Philippines, Poland, Portugal, Romania, Russia, Singapore, Serbia, Slovakia, Slovenia, Sweden, Thailand, Tunisia, Turkey, Ukraine, Uruguay, the United States, South Africa. Data are available at the earliest for 1960, and the latest data included in the regression sample are for year 2014 (last five-year complete cycle), but the sample is unbalanced. 
Table 2

Conditional beta convergence: TFP

\begin{tabular}{|c|c|c|c|c|c|c|c|c|c|}
\hline Dep var. TFP growth & $\begin{array}{c}(1) \\
\text { All } \\
\text { sample }\end{array}$ & $\begin{array}{c}\text { (2) } \\
\text { All } \\
\text { sample }\end{array}$ & $\begin{array}{l}\text { (3) } \\
\text { EU }\end{array}$ & $\begin{array}{l}(4) \\
E A\end{array}$ & $\begin{array}{c}(5) \\
\text { EA11 }\end{array}$ & $\begin{array}{c}\text { (6) } \\
\text { EA } \\
1999-2007\end{array}$ & $\begin{array}{c}(7) \\
E A>2007\end{array}$ & $\begin{array}{c}(8) \\
\text { EA11, } \\
1960-2007\end{array}$ & $\begin{array}{c}(9) \\
\text { EA11 }>2007\end{array}$ \\
\hline Log TFP level PPP, 5lag & $\begin{array}{c}-1.537^{\star *} \\
{[-4.88]}\end{array}$ & $\begin{array}{l}-1.499^{\star *} \\
{[-4.73]}\end{array}$ & $\begin{array}{l}-2.064^{\star \star} \\
{[-4.41]}\end{array}$ & $\begin{array}{l}-2.058^{\star} \\
{[-2.76]}\end{array}$ & $\begin{array}{l}0.500 \\
{[1.04]}\end{array}$ & $\begin{array}{l}-3.900^{\star *} \\
{[-5.10]}\end{array}$ & $\begin{array}{l}-1.983+ \\
{[-1.98]}\end{array}$ & $\begin{array}{c}0.035 \\
{[0.07]}\end{array}$ & $\begin{array}{l}3.539+ \\
{[2.06]}\end{array}$ \\
\hline Avg. schooling, 5 lags & $\begin{array}{l}0.337+ \\
{[1.75]}\end{array}$ & & & & & & & & \\
\hline I/GDP, avg & $\begin{array}{l}-0.496 \\
{[-0.45]}\end{array}$ & & & & & & & & \\
\hline Economic freedom, avg. & $\begin{array}{l}0.201^{*} \\
{[2.09]}\end{array}$ & $\begin{array}{l}0.241^{\text {** }} \\
{[2.93]}\end{array}$ & $\begin{array}{l}0.386^{\star *} \\
{[3.01]}\end{array}$ & $\begin{array}{l}0.340 \\
{[1.31]}\end{array}$ & $\begin{array}{l}0.880^{\star *} \\
{[4.06]}\end{array}$ & $\begin{array}{c}0.389 \\
{[0.98]}\end{array}$ & $\begin{array}{l}2.580+ \\
{[2.05]}\end{array}$ & $\begin{array}{l}0.845^{\star \star} \\
{[4.19]}\end{array}$ & $\begin{array}{l}1.827+ \\
{[1.94]}\end{array}$ \\
\hline Openness, avg. & $\begin{array}{r}0.153 \\
{[0.59]}\end{array}$ & & & & & & & & \\
\hline Observations & 502 & 502 & 203 & 143 & 99 & 38 & 19 & 88 & 11 \\
\hline Countries & 64 & 64 & 28 & 19 & 11 & 19 & 19 & 11 & 11 \\
\hline R-squared & 0.25 & 0.25 & 0.30 & 0.36 & 0.55 & 0.64 & 0.35 & 0.55 & 0.81 \\
\hline
\end{tabular}

Note: Constant, time effects and region effects included. Robust (clustered) t-statistics in brackets. ${ }^{* *} p<0.01,{ }^{*} p<0.05,+p<0.1$.

Source: Authors' estimation.

unchanged when using instrumental variables estimation, using the price of investment goods as an instrument for investment, as is customary in related literature..$^{10}$

For the whole sample of countries, there is evidence of beta convergence as the coefficient on the logarithm of the initial GDP per capita is negative and statistically significant, providing therefore support to the catchingup hypothesis. This is also the case for the EU (column 3) and for the euro area (column 4), but not for the EA11 (column 5). Looking only at the period after euro adoption (columns 6-8), the same results still hold for the euro area, the EU and the EA11. However, looking at the period after 2007, which includes mostly the global financial crisis and the European sovereign debt crisis, evidence of convergence for the euro area and the EU becomes weaker (columns 9 and 10). In the case of the EA11, after 2007 the evidence points to divergence rather than convergence, as the coefficient for initial per capita income becomes positive, although insignificant in column $11 .{ }^{11}$

10 Exogeneity tests also indicate that investment can be treated as exogenous. Tests for exogeneity and validity of instruments are reported in Table 1.

11 The estimation results for the shorter sample starting after 2007 are only indicative as the number of observations is small. In particular, inference for this sample should be viewed with caution throughout the analysis.
Growth regressions have also been run to test for convergence in TFP growth. Table 2 shows the estimation results. Initial TFP, human capital, investment, institutions (Fraser index) and openness have all been considered as possible control variables. Initial TFP is expected to be negatively associated with TFP growth as laggard countries have more room to grow by adopting existing technologies. Human capital controls for the fact that countries with a more educated population tend to innovate more. The variable that measures institutional quality accounts for different incentives for innovation and entrepreneurship. Openness controls for the degree of impediments to technology absorption. Apart from initial TFP levels and institutions, other control variables appear to be statistically insignificant in explaining TFP growth (column 1). Once restricting the specification to significant variables in column 2 , the coefficient for initial TFP levels are barely affected. Columns 3-9 therefore use this restricted specification, controlling only for initial TFP and institutions captured by the Fraser index.

Results provide evidence that TFP convergence exists among the whole sample of countries (columns 1 and 2), as well as for the EU and the euro area (columns 3 and 4). There is instead no evidence of convergence for the EA11, and TFP appears to diverge over the period following the financial crisis (columns 5, 8 and 9). Conversely, there is evidence of convergence across the EU as a 
Figure 10

Actual growth rates in GDP per capita and predictions from growth regressions

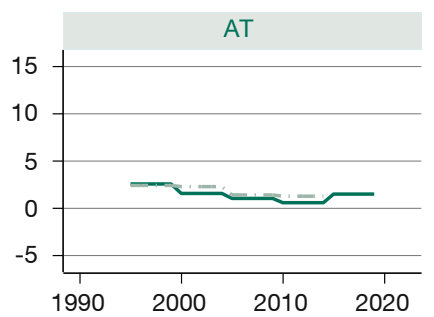

ES

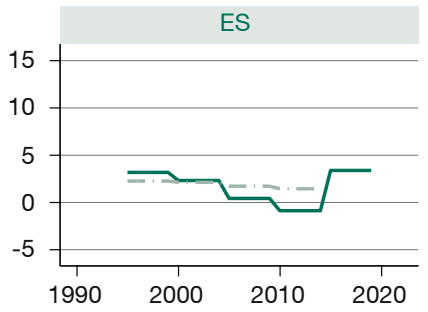

IT

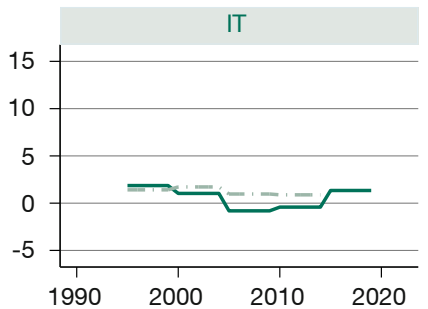

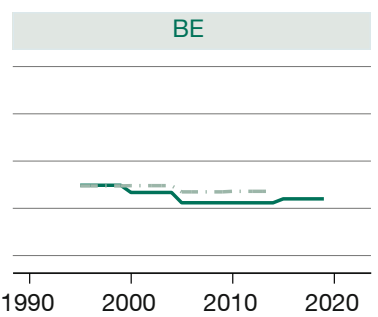

$\mathrm{FI}$
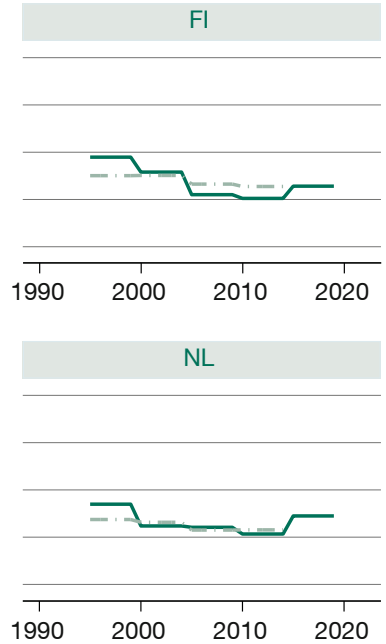
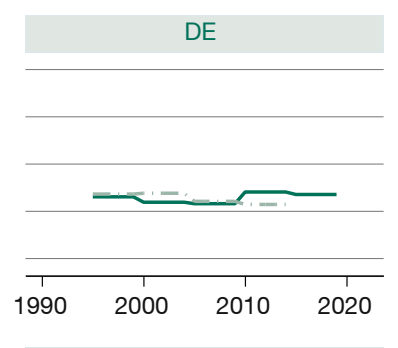

FR
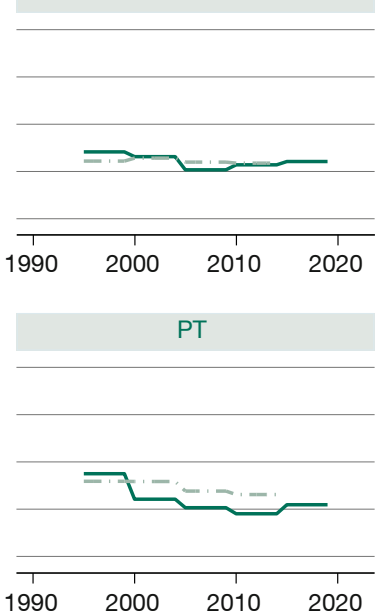

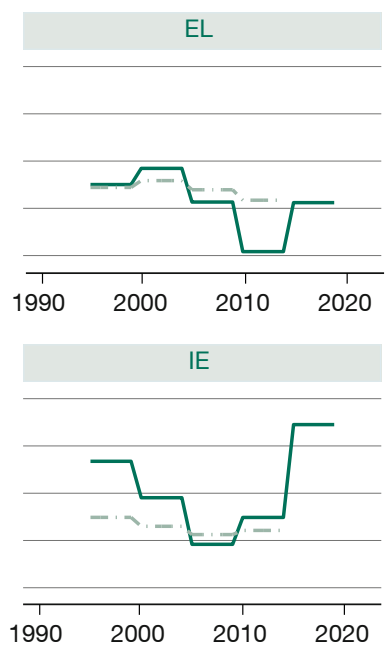

Average real GDP growth p.h., PPPs

Prediction from growth regression

Sources: PWT 9.1 and authors' estimations

whole even for the post-crisis sub-sample (columns 6 and 7).

Deviations from convergence paths: A role for macroeconomic imbalances?

What factors could have been responsible for the lack of convergence across the euro area? Did macroeconomic imbalances play a role? To answer these questions, a first necessary step is to construct a measure of the 'convergence gaps', namely quantify the gap between actual growth and the growth paths to steady-state growth rates expected on the basis of the relevant characteristics of countries, i.e. the initial level of output per capita and all other conditioning factors. These paths are obtained using the prediction from the regression estimated on the largest panel of countries and sample period (column 1, Table 1 for GDP and column 2, Table 2 for TFP). The predictions are based on the full sample to obtain more robust and less distorted estimates. As an illustration, Figure 10 plots actual GDP growth with the predicted growth paths for GDP for euro area countries over five-year periods.
The second step is to relate deviations of per capita GDP (or TFP) from these predicted convergence paths to variables reflecting the presence of macroeconomic imbalances. Figures 11 and 12 indicate some correlation between deviations and stocks of private debt and current accounts, respectively. To simultaneously take into account the role of different sources of macroeconomic imbalances, a multivariate regression analysis is carried out. To formally test for the role that imbalances have played in the convergence process, regression (5) is estimated using OLS:

$$
\varepsilon_{i t}=\alpha+\lambda I M B_{i t-5}+\gamma_{i}+\delta_{t}+u_{i t},
$$

where $\varepsilon_{i t}$ measures the convergence gap from GDP per capita or TFP regressions (i.e. the residuals obtained from the regressions estimated on the full sample, see Table 1 and Table 2), while IMB stands for a set of variables associated with macroeconomic imbalances. Six variables reflecting possible macro-economic imbalances are considered: (i) the initial private debt-to-GDP ratio; (ii) the initial government debt-to-GDP ratio; (iii) the initial net international investment position (NIIP) in percent of GDP; (iv) credit to the private sector as a share 
Figure 11

Convergence gaps and private debt stocks

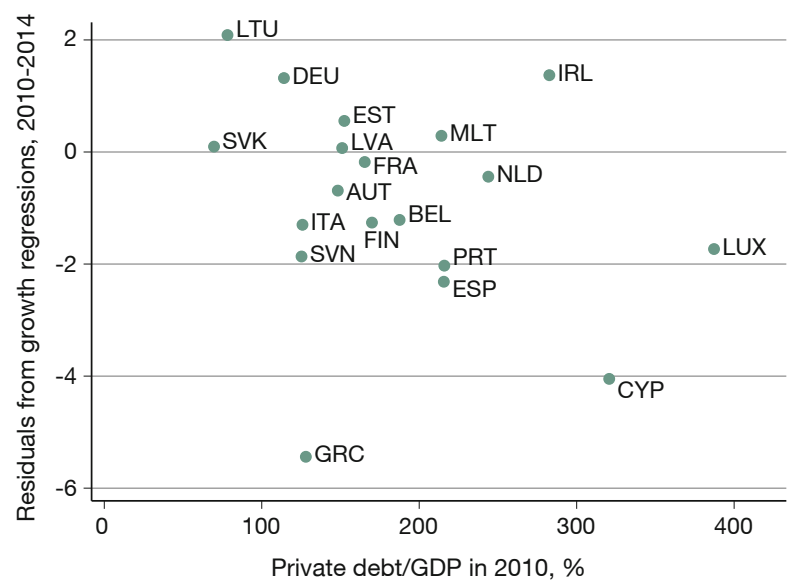

Source: Eurostat and authors' estimations.

of GDP; (v) the current account gap; and (vi) the share of construction in total value added, as a proxy for changes in the weight of the non-tradable sector. ${ }^{12}$ The credit

12 In Lukmanova and Tondl (2017), the excess weight of non-tradables is captured by the growth in unit labour costs. The two variables correlate and the weight of the construction sector in total gross value added is available for a broader set of countries.
Figure 12

Convergence gaps and current accounts

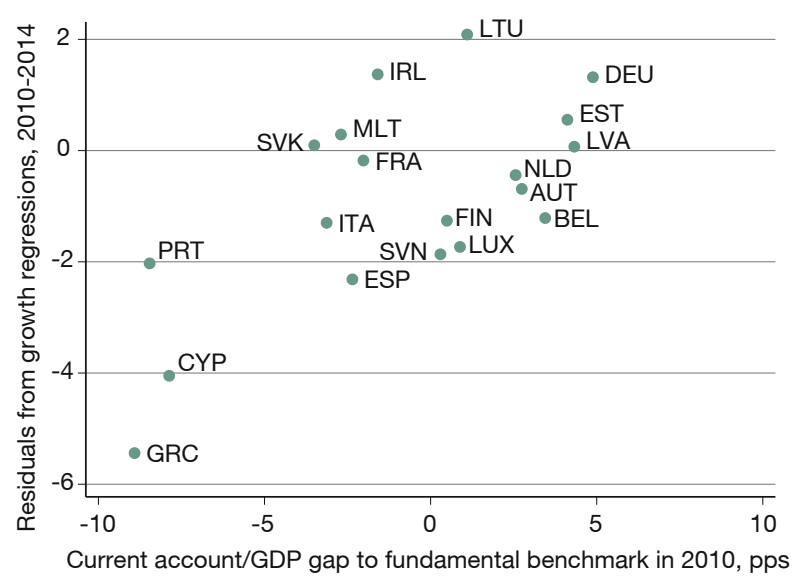

Source: Eurostat and authors' estimations.

variable and the construction share are both demeaned by the country long-term average to allow for different economic structures. The current account gap is estimated as the difference between the actual current account balance as a share of GDP and the one that can be explained by the fundamentals of the economy (current account norm), following the methodology proposed in

Table 3

Deviations from convergence paths and macroeconomic imbalances

\begin{tabular}{|c|c|c|c|c|c|c|c|c|}
\hline & \multicolumn{4}{|c|}{ GDP growth residuals } & \multicolumn{4}{|c|}{ TFP growth residuals } \\
\hline & $\begin{array}{c}(1) \\
E A>1999\end{array}$ & $\begin{array}{c}(2) \\
\text { Non- } \\
E A>1999\end{array}$ & $\begin{array}{c}(3) \\
E A>2007\end{array}$ & $\begin{array}{c}(4) \\
\text { Non- } \\
E A>2007\end{array}$ & $\begin{array}{c}(5) \\
E A>1999\end{array}$ & $\begin{array}{c}(6) \\
\text { Non- } \\
E A>1999\end{array}$ & $\begin{array}{c}(7) \\
E A>2007\end{array}$ & $\begin{array}{c}\text { (8) } \\
\text { Non- } \\
\text { EA }>2007\end{array}$ \\
\hline Private debt/GDP, 5 lags & $\begin{array}{l}-0.009^{\star *} \\
{[-3.78]}\end{array}$ & $\begin{array}{l}-0.014^{\star \star} \\
{[-4.13]}\end{array}$ & $\begin{array}{l}-0.014^{\star \star} \\
{[-3.33]}\end{array}$ & $\begin{array}{l}-0.001 \\
{[-0.18]}\end{array}$ & $\begin{array}{l}-0.005^{\star} \\
{[-2.53]}\end{array}$ & $\begin{array}{l}-0.009^{\star \star} \\
{[-2.76]}\end{array}$ & $\begin{array}{l}-0.007^{\star} \\
{[-2.34]}\end{array}$ & $\begin{array}{r}0.001 \\
{[0.32]}\end{array}$ \\
\hline Gov. debt/GDP, 5 lags & $\begin{array}{l}-0.029^{\star \star} \\
{[-5.67]}\end{array}$ & $\begin{array}{l}-0.005 \\
{[-1.35]}\end{array}$ & $\begin{array}{l}-0.035^{\star} \\
{[-2.31]}\end{array}$ & $\begin{array}{l}-0.000 \\
{[-0.05]}\end{array}$ & $\begin{array}{l}-0.025^{\star \star} \\
{[-5.39]}\end{array}$ & $\begin{array}{l}-0.005 \\
{[-1.57]}\end{array}$ & $\begin{array}{l}-0.027+ \\
{[-2.09]}\end{array}$ & $\begin{array}{l}0.001 \\
{[0.21]}\end{array}$ \\
\hline NIIP/GDP, 5 lags & $\begin{array}{l}0.009^{*} \\
{[2.72]}\end{array}$ & $\begin{array}{l}-0.002 \\
{[-0.79]}\end{array}$ & $\begin{array}{l}0.015+ \\
{[1.97]}\end{array}$ & $\begin{array}{l}-0.001 \\
{[-0.15]}\end{array}$ & $\begin{array}{l}0.006+ \\
{[1.99]}\end{array}$ & $\begin{array}{l}-0.000 \\
{[-0.12]}\end{array}$ & $\begin{array}{l}0.008 \\
{[1.27]}\end{array}$ & $\begin{array}{l}0.002 \\
{[0.76]}\end{array}$ \\
\hline $\begin{array}{l}\text { Credit flow/GDP, } 5 \text { lags } \\
\text { (relative to country long-term average) }\end{array}$ & $\begin{array}{l}0.018+ \\
{[2.00]}\end{array}$ & $\begin{array}{l}0.025+ \\
{[1.78]}\end{array}$ & $\begin{array}{r}-0.012 \\
{[-0.63]}\end{array}$ & $\begin{array}{r}-0.017 \\
{[-0.54]}\end{array}$ & $\begin{array}{r}0.016 \\
{[1.53]}\end{array}$ & $\begin{array}{c}0.002 \\
{[0.23]}\end{array}$ & $\begin{array}{l}0.006 \\
{[0.44]}\end{array}$ & $\begin{array}{r}0.001 \\
{[0.07]}\end{array}$ \\
\hline Current account gap, 5 lags & $\begin{array}{r}0.018 \\
{[0.56]}\end{array}$ & $\begin{array}{l}0.092+ \\
{[1.94]}\end{array}$ & $\begin{array}{c}0.033 \\
{[0.34]}\end{array}$ & $\begin{array}{l}-0.030 \\
{[-0.34]}\end{array}$ & $\begin{array}{l}-0.000 \\
{[-0.01]}\end{array}$ & $\begin{array}{l}0.048 \\
{[1.64]}\end{array}$ & $\begin{array}{c}0.005 \\
{[0.06]}\end{array}$ & $\begin{array}{l}-0.030 \\
{[-0.80]}\end{array}$ \\
\hline $\begin{array}{l}\text { Construction VA share, } 5 \text { lags } \\
\text { (relative to country long-term average) }\end{array}$ & $\begin{array}{l}-0.579^{\star *} \\
{[-3.21]}\end{array}$ & $\begin{array}{l}-0.228+ \\
{[-1.75]}\end{array}$ & $\begin{array}{l}-0.929^{\star \star} \\
{[-3.85]}\end{array}$ & $\begin{array}{l}-0.317 \\
{[-1.39]}\end{array}$ & $\begin{array}{l}-0.500^{\star *} \\
{[-3.58]}\end{array}$ & $\begin{array}{r}-0.133 \\
{[-0.96]}\end{array}$ & $\begin{array}{l}-0.623^{\star \star} \\
{[-2.88]}\end{array}$ & $\begin{array}{r}0.047 \\
{[0.39]}\end{array}$ \\
\hline Observations & 53 & 93 & 19 & 32 & 53 & 93 & 19 & 32 \\
\hline Countries & 19 & 32 & 19 & 32 & 19 & 32 & 19 & 32 \\
\hline R-squared & 0.53 & 0.36 & 0.72 & 0.36 & 0.50 & 0.26 & 0.62 & 0.41 \\
\hline
\end{tabular}

Note: Robust t-statistics in brackets. Constant, time effects and regional effects included. ${ }^{* \star} p<0.01,{ }^{*} p<0.05,+p<01$

Source: Eurostat and authors' estimation. 
Coutinho et al. (2018). The main data sources are Eurostat and AMECO. For non-EU countries, these sources were complemented with data from the World Economic Outlook and the Bank of International Settlements databases.

Table 3 shows the results, displayed separately for the euro area and for a comparison group consisting of all countries in the sample except the euro area. It also shows two sample splits in time: after 1999, the year when the euro was introduced, and after 2007, i.e. after the eruption of the financial crisis. Results are displayed both for convergence gaps relating to GDP per capita growth and to TFP growth.

For the sample starting in 1999, private debt, government debt, NIIP and the share of construction are significant in explaining euro area GDP per capita convergence gaps. The corresponding coefficients have the expected signs. By looking at results for non-euro area countries, a loss in significance is observed for all variables except private debt, while current accounts acquire some explanatory power. Results remain similar for the euro area when restricting the analysis to the post-crisis period. Wald tests fail to reject the null hypothesis that the estimated coefficients for the two sub-periods are equal at the $95 \%$ confidence level. Conversely, for non-euro area countries, the significance is lost for all variables.

Overall, this evidence indicates that high private debt is significantly associated with subsequent growth below the one expected on the basis of fundamentals. This result appears robust across country groups and time. For the euro area, high public debt and a high weight of non-tradables in output also seem important in driving growth below expected paths. As for external imbalances, the results are less robust. Deviations from TFP growth paths are confirmed in the euro area especially the role of private debt and the tradable sector, while for non-euro area countries, a significant role is found only for private debt.

The above results suggest an association between convergence gaps and macroeconomic imbalances, and that this association presents particular features in the case of euro area countries. The relatively stronger role of government debt in explaining convergence gaps of euro area countries is consistent with the fact that the probability of bond market tensions increases with the size of debt. As government debt is higher on average in euro area countries and since bond market tensions affect growth notably via reduced credit availability linked to sovereign-bank doom loops, one should expect a stronger impact of government debt on subsequent convergence paths for euro area countries. ${ }^{13}$ Current accounts seem instead less important for euro area countries in explaining deviations from convergence paths. A possible interpretation is that the liquidity provision by the European System of Central Banks helps mitigate the real effects of current account sudden stops (Merler and Pisani-Ferry, 2012). Finally, convergence paths among euro area countries appear to be comparatively more related to the growth in the nontradable sector. The narrowing of interest rate differentials in the euro area periphery, as a result of the monetary union, was matched by capital inflows largely channelled into the construction sector and other non-tradable activities. The fact that resources were largely absorbed in non-tradable activities meant the euro area periphery had less room to grow out of exports when domestic demand became constrained by deleveraging needs. Moreover, as TFP growth is generally faster in the tradable sector, the growth of construction and non-tradable activities was associated with subsequent disappointing growth rates in TFP.

\section{Conclusions}

This paper reviews convergence patterns across the euro area and analyses the role of macroeconomic imbalances in providing a possible explanation for lack of convergence in the post-crisis period. The analysis shows that convergence in the euro area was similar to that observed among other country groups, while convergence within the EA11 (founding members excluding Luxembourg) has been lacking since the 1980s, in light of persistent absence of TFP convergence and partly associated with the fact that this is an already relatively homogeneous group in terms of per capita income. Post-crisis divergent employment rates reinforced this pattern.

Our analysis also shows that deviations from expected convergence paths are associated with a number of initial conditions, which summarise the presence of macroeconomic imbalances - private debt in particular. Most interestingly, convergence gaps within the euro area seem to be affected by a number of peculiar factors, notably government debt and the share of the non-tradable sector on value added, which do not play a significant role in a comparison group. Convergence gaps across euro area countries also appear to have been comparatively less affected by external imbalances, possibly in light of the more limited extent of current account reversals within the euro area.

13 For evidence on the relation between government debt and credit risk on government bonds, see Bernoth et al. (2012). De Grauwe and Ji (2013) also find that bond spreads are more sensitive to investor sentiment in countries of a monetary union than in stand-alone countries. 
Overall, the analysis underscores the importance of conditions ensuring macro stability and resilience for economic convergence. Preventing the accumulation of excessive private debt is particularly important both inside and outside the euro area. In addition, there is a specific role for maintaining prudent levels of public debt and running prudent fiscal policies within the euro area. An important policy implication is that sustainable convergence requires addressing legacy imbalances.

\section{References}

Aghion, P. and P. Howitt (2006), Joseph Schumpeter lecture appropriate growth policy: A unifying framework, Journal of the European Economic Association, 4(2-3), 269-314.

Barro, R. J. and X. Sala-i-Martin (2004), Economic Growth, MIT Press.

Blanchard, O. and F. Giavazzi (2002), Current account deficits in the euro area: the end of the Feldstein-Horioka puzzle?, Brookings Papers on Economic Activity, 2, 148-186.

Böwer, U. and A. Turrini (2010), EU Accession: A Road to Fast-track Convergence?, Comparative Economic Studies, 52, 181-205.

Buti, M. and A. Turrini (2015, 17 April), Three waves of convergence. Can Eurozone countries start growing together again?, VoxEU, https:// voxeu.org/article/types-ez-convergence-nominal-real-and-structural (21 August 2020).

Coutinho, L., A. Turrini and S. Zeugner (2018), Methodologies for the Assessment of Current Account Benchmarks, European Economy Discussion Paper, 086.

De Grauwe, P. and Y. Ji (2013), Self-fulfilling crises in the Eurozone: An empirical test, Journal of International Money and Finance, 34, 15-36.

Diaz del Hoyo, J.-L., E. Dorrucci, F. F. Heinz and S. Muzikarova (2017), Real convergence in the euro área: a long-term perspective, European Central Bank Occasional Paper, 203.

ECB (2015), Real convergence in the euro area: evidence, theory and policy implications, European Central Bank Economic Bulletin, 5.

Edwards, S. (1998), Openness, productivity and growth: what do we really know?, The Economic Journal, 108(447), 383-398.

Estrada, Á. and D. López-Salido (2013), Patterns of convergence and divergence in the euro area, IMF Economic Review, 61(4), 601-630.

Frankel, J. A. and D. H. Romer (1999), Does trade cause growth?, American Economic Review, 89(3), 379-399.

Glaeser, E. L., R. La Porta, F. Lopez-de-Silanes and A. Shleifer (2004), Do institutions cause growth?, Journal of Economic Growth, 9(3), 271-303.

Inklaar, R. and P. Woltjer (2019), What is new in PWT 9.1?, University of Groningen.

Inklaar, R., R. Jong-A-Pin and J. de Haan (2008), Will business cycles in the euro area converge? A critical survey of empirical research, Journal of Economic Surveys, 22(2), 234-273.

Lukmanova, E. and G. (2017), Macroeconomic imbalances and business cycle synchronisation. Why common governance is imperative in the Eurozone, Economic Modelling, 62, 130-144.

Mankiw, N. G., D. Romer and D. N. Weil (1992), A contribution to the empirics of economic growth, Quarterly Journal of Economics, 107, 407437.

Merler, S. and J. Pisani-Ferry (2012), Sudden stops in the euro area, Bruegel Policy Contribution, 2012/06.

Mundell, R. A. (1961), A theory of optimum currency areas, The American Economic Review, 51(4), 657-665.

Solow, R. (1956), A contribution to the theory of economic growth, Quarterly Journal of Economics, 70(1), 65-94.

Sondermann, D. (2014), Productivity in the euro area: any evidence of convergence?, Empirical Economics, 47(3), 999-1027.

Swan, T. (1956), Economic growth and capital accumulation, Economic Record, 32(63), 334-361.

Temple, J. (1999), The new growth evidence, Journal of Economic Literature, 37(1), 112-156. 